\title{
Penerapan Fuzzy C-Means untuk Deteksi Dini Kemampuan Penalaran Matematis
}

\author{
Muh. Nurtanzis Sutoyo ${ }^{1}$, Andi Tenri Sumpala ${ }^{2}$ \\ ${ }^{1,2}$ Program Studi Sistem Informasi, FTI, Universitas Sembilanbelas November Kolaka \\ Email: ${ }^{1} \mathrm{mr}$. iyes@yahoo.co.id, ${ }^{2}$ foleta_21@gmail.com
}

\begin{abstract}
Abstrak
Penalaran matematis (mathematical reasoning) merupakan suatu proses berpikir yang dilakukan dengan cara untuk menarik kesimpulan. Penerapan data mining dapat membantu menganalisa data yang diperoleh dari kondisi kemampuan penalaran matematis. Teknik data mining yang digunakan adalah dengan menggunakan teknik clustering. Salah satu metode clustering adalah algoritma Fuzzy C-Means. Fuzzy C-Means memiliki tingkat akurasi yang tinggi dan waktu komputasi yang cepat. Uji validitas hasil clustering untuk deteksi dini kemampuan penalaran matematis dengan menggunakan perhitungan Partition Coeffecient (PC) diperoleh 0.840, ini berarti dapat dikatakan bahwa hasil clustering tergolong dalam kategori baik. Dari hasil perhitungan diperoleh 11 orang $(25 \%)$ yang memiliki kemampuan penalaran matematis baik, sebanyak 25 orang (57\%) memiliki kemampuan penalaran matematis cukup, dan sebanyak $8(18 \%)$ orang memiliki kemampuan penalaran matematis yang kurang.
\end{abstract}

Kata Kunci: Fuzzy C-Means, Kemampuan Penalaran Matematis

\section{PENDAHULUAN}

Pendidikan merupakan salah satu bentuk upaya sadar yang bertujuan untuk menyiapkan subyek pendidikan dalam menghadapi lingkungan yang terus mengalami perubahan, sehingga dari pendidikan tersebut diharapkan subyek didik mampu merespon masyarakat. Salah satu tujuan Pendidikan Tinggi adalah menghasilkannya lulusan yang menguasai cabang ilmu pengetahuan atau teknologi untuk memenuhi kepentingan nasional dan peningkatan daya saing bangsa [1].

Ilmu Komputer (computer Science), secara umum diartikan sebagai ilmu yang mempelajari baik tentang komputasi, perangkat keras (hardware) maupun perangkat lunak (software). Ilmu komputer mencakup beragam topik yang berkaitan dengan komputer, mulai dari analisa abstrak algoritma sampai subyek yang lebih konkret seperti bahasa pemrograman, perangkat lunak, termasuk perangkat keras. Sebagai suatu disiplin ilmu, Ilmu Komputer lebih menekankan pada pemrograman komputer, dan rekayasa perangkat lunak (software), sementara teknik komputer lebih cenderung berkaitan dengan hal-hal seperti perangkat keras komputer (hardware). Namun demikian, kedua istilah tersebut sering disalah-artikan oleh banyak orang [2].

Salah satu kemampuan yang dapat menjadi bekal dalam menguasai Ilmu Komputer adalah keahlian kemampuan dasar matematika. Secara garis besar, kemampuan dasar matematika dapat diklasifikasikan dalam lima standar kemampuan, yaitu: pemahaman matematika, pemecahan masalah matematika, penalaran matematika (mathematical reasoning), koneksi matematik (mathematical connection), dan komunikasi matematik (mathematical communication) [3]. 
Kemampuan penalaran (reasoning) merupakan salah satu komponen proses standar dalam Principles and Standards for School Mathematics selain kemampuan pemecahan masalah, representasi, komunikasi dan koneksi. Penalaran matematis (mathematical reasoning) merupakan suatu proses berpikir yang dilakukan dengan cara untuk menarik kesimpulan. Penalaran matematis penting untuk mengetahui dan mengerjakan matematika. Kemampuan untuk bernalar menjadikan siswa dapat memecahkan masalah dalam kehidupannya, di dalam dan di luar sekolah [4].

Penerapan data mining dapat membantu menganalisa data yang diperoleh dari kondisi kemampuan penalaran matematis. Teknik data mining yang digunakan adalah dengan menggunakan teknik clustering. Teknik clustering digunakan pada data mining untuk mengelompokan objek-objek yang memiliki kemiripan dalam kelas yang sama [5]. Salah satu metode clustering adalah menggunakan metode fuzzy clustering, yaitu dengan algoritma Fuzzy C-Means. Dimana Fuzzy C-Means memiliki tingkat akurasi yang tinggi dan waktu komputasi yang cepat[6].

Dengan mengetahui kemampuan dasar mahasiswa dapat dijadikan masukan dalam pembagian ruangan (kelompok belajar) atau strategi pembelajaran yang akan digunakan. Aspek-aspek kemampuan penalaran adalah aljabar, geometri, aritmatika, dan statistik.

\section{METODE}

\subsection{Fuzzy C-Means}

Fuzzy clustering adalah bagian dari pattern recognition atau pengenalan pola. Fuzzy clustering memainkan peran yang paling penting dalam pencarian struktur dalam data. Fuzzy clustering adalah salah satu teknik untuk menentukan cluster optimal dalam suatu ruang vektor yang didasarkan pada bentuk normal Euclidian untuk jarak antar vektor. Fuzzy clustering adalah salah satu teknik untuk menentukan cluster optimal dalam suatu ruang vektor yang didasarkan pada bentuk normal Euclidian untuk jarak antar vektor. Fuzzy $C$-Means adalah suatu teknik pengclusteran data yang mana keberadaan tiap-tiap titik data dalam suatu cluster ditentukan oleh derajat keanggotaan [7].

Konsep dasar Fuzzy C-Means, pertama kali adalah menentukan pusat cluster, yang akan menandai lokasi rata-rata untuk tiap-tiap cluster. Pada kondisi awal, pusat cluster ini masih belum akurat. Tiap-tiap titik data memiliki derajat keanggotaan untuk tiap-tiap cluster. Adapun algoritma Fuzzy C-Means adalah sebagai berikut [8].

1. Input data yang akan dicluster $\mathrm{X}$, berupa matriks berukuran $\mathrm{n} \times \mathrm{m}(\mathrm{n}=$ jumlah sampel data, $m=$ atribut setiap data). $\mathrm{X}_{\mathrm{ij}}=$ data sampel ke-i $(\mathrm{i}=1,2, \ldots, \mathrm{n})$, atribut ke-j $(\mathrm{j}=1,2, \ldots, \mathrm{m})$.

2. Tentukan:
a) Jumlah cluster $=\mathrm{c}$
b) Pangkat $=\mathrm{w}$
c) Maksimum iterasi= Maxlter
d) Error terkecil yang diharapkan $=\xi$
e) Fungsi obyektif, $\mathrm{P}_{0}=0$
f) Iterasi awal, $\mathrm{t}=1$ 
3. Bangkitkan bilangan random $\mu_{\mathrm{ik}}, \mathrm{i}=1,2, \ldots, \mathrm{n} ; \mathrm{k}=1,2, \ldots, \mathrm{c}$; sebagai elemen-elemen matriks partisi awal U. Hitung jumlah setiap kolom:

$$
Q_{i}=\sum_{k=1}^{c} \mu_{i k}
$$

Dengan $\mathrm{j}=1,2, \ldots, \mathrm{n}$. Hitung:

$$
\mu_{i k}=\frac{\mu_{i k}}{Q_{i}}
$$

4. Hitung pusat cluster $\mathrm{ke}-\mathrm{k}$ : $\mathrm{V}_{\mathrm{kj}}$, dengan $\mathrm{k}=1,2, \ldots, \mathrm{c} ;$ dan $\mathrm{j}=1,2, \ldots, \mathrm{m}$.

$$
V_{k j}=\frac{\sum_{i=1}^{n}\left(\left(\mu_{i k}\right)^{w} * X_{i j}\right)}{\sum_{i=1}^{n}\left(\mu_{i k}\right)^{w}}
$$

5. Hitung fungsi obyektif pada iterasi ke-t, $\mathrm{P}_{\mathrm{t}}$ :

$$
P_{t}=\sum_{i=1}^{n} \sum_{k=1}^{c}\left(\left[\sum_{j=1}^{m}\left(X_{i j}-V_{k j}\right)^{2}\right]\left(\mu_{i k}\right)^{w}\right)
$$

6. Hitung perubahan matriks partisi:

$$
\mu i k=\frac{\left[\sum_{j=1}^{m}\left(X_{i j}-V_{k j}\right)^{2}\right]^{\frac{-1}{w-1}}}{\sum_{k=1}^{c}\left[\sum_{j=1}^{m}\left(X_{i j}-V_{k j}\right)^{2}\right]^{\frac{-1}{w-1}}}
$$

dengan: $\mathrm{i}=1,2, \ldots, \mathrm{n}$; dan $\mathrm{k}=1,2, \ldots, \mathrm{c}$

7. Cek kondisi berhenti:

- Jika: $\left(\left|\mathrm{P}_{\mathrm{t}}-\mathrm{P}_{\mathrm{t}-1}\right|<\xi\right)$ atau $(\mathrm{t}>$ MaxIter) maka berhenti.

- Jika tidak: $\mathrm{t}=\mathrm{t}+1$, ulangi langkah ke-4.

\subsection{Validitas Clustering}

Sedangkan untuk menguji validitas hasil clustering dengan pendekatan Fuzzy Clustering, digunakan perhitungan koefesien partisi atau Partition Coeffecient (PC). Partition Coeffecient (PC) sebagai evaluasi data pada setiap cluster, dimana nilai Partition Coeffecient (PC) hanya mengevaluasi nilai derajat keanggotaan dan tanpa memandang nilai data yang mengandung informasi [9]. Rumus yang digunakan untuk menghitung validitas Partition Coeffecient (PC) adalah

$$
P C=\sum_{k=1}^{n} \sum_{i=1}^{c}\left(u_{i k}\right)^{2} / n
$$

dimana $n$ merupakan jumlah data, $c$ jumlah cluster, dan $u_{i k}$ menyatakan nilai keanggotaan dari data ke- $k$ pada cluster ke- $i$. Nilai hasil uji validitas dalam rentang $[0$, 
1], nilai yang semakin besar (mendekati 1) mempunyai arti bahwa kualitas cluster yang didapat semakin baik.

\subsection{Kemampuan Penalaran Matematis}

Kemampuan merupakan kata benda dari kata mampu yang berarti kuasa (bisa, sanggup) melakukan sesuatu, sehingga kemampuan dapat diartikan kesanggupan. Sedangkan penalaran adalah sebagai secara garis besar terdapat 2 jenis penalaran yaitu penalaran deduktif yang disebut pula deduksi dan penalaran induktif yang disebut pula induksi. Penalaran memerlukan landasan logika. Penalaran dalam logika bukan suatu proses mengingat-ingat, menghafal ataupun mengkhayal. Tetapi merupakan rangkaian proses mencari keterangan lain sebelumnya [4].

Sehingga dapat disimpulkan bahwa penalaran matematika adalah proses berpikir untuk menentukan apakah sebuah argumen matematika benar atau salah dan juga dipakai untuk membangun suatu argumen matematika baru.

Setelah dilakukan penskoran berdasarkan indikator kemampuan penalaran matematis. Data yang didapat dari penskoran dikategorikan kedalam 3 (tiga) kategori, yaitu: baik, cukup, dan kurang. Dimana metode pengelompokkan menggunakan Fuzzy C-Means.

\section{HASIL DAN PEMBAHASAN}

Diketahui nilai kemampuan penalaran matematis dari 44 orang mahasiswa seperti pada Tabel 1.

Tabel 1. Nilai kemampuan penalaran matematis

\begin{tabular}{cccccc}
\hline No & Aritmatika & Statistika & No & Aritmatika & Statistika \\
\hline 1 & 60 & 67 & 23 & 74 & 81 \\
2 & 67 & 74 & 24 & 91 & 98 \\
3 & 74 & 81 & 25 & 58 & 65 \\
4 & 67 & 74 & 26 & 23 & 30 \\
5 & 92 & 99 & 27 & 86 & 93 \\
6 & 74 & 81 & 28 & 67 & 74 \\
7 & 93 & 97 & 29 & 85 & 92 \\
8 & 45 & 52 & 30 & 93 & 94 \\
9 & 64 & 71 & 31 & 69 & 76 \\
10 & 85 & 92 & 32 & 47 & 54 \\
11 & 69 & 76 & 33 & 63 & 70 \\
12 & 58 & 65 & 34 & 55 & 62 \\
13 & 63 & 70 & 35 & 74 & 81 \\
14 & 64 & 71 & 36 & 23 & 30 \\
15 & 39 & 46 & 37 & 98 & 87 \\
16 & 63 & 70 & 38 & 33 & 40 \\
17 & 60 & 67 & 39 & 60 & 67 \\
18 & 69 & 76 & 40 & 73 & 80 \\
19 & 74 & 81 & 41 & 33 & 40 \\
20 & 83 & 90 & 42 & 83 & 90 \\
21 & 60 & 67 & 43 & 69 & 76 \\
22 & 95 & 98 & 44 & 41 & 48 \\
\hline
\end{tabular}

Berdasarkan nilai kemampuan penalaran matematis di atas, dikelompokkan kedalam 3 cluster yaitu baik, cukup dan kurang. Parameter yang digunakan dalam proses pengcluster-an dengan menggunakan algoritma Fuzzy C-Means adalah sebagai berikut: 
a) Jumlah cluster (c) = $=3$

b) Pangkat (w) = 2

c) Maksimum iterasi (Maxlter) $\quad=100$

d) Error terkecil yang diharapkan $(\xi) \quad=10^{-5}$

Berdasarkan hasil perhitungan iterasi-1 diperoleh nilai V (pusat cluster) pada iterasi ke-1 adalah sebagai berikut:

$$
V=\left(\begin{array}{ll}
67.13 & 73.43 \\
65.77 & 72.29 \\
64.64 & 70.87
\end{array}\right)
$$

Dengan fungsi obyektif pada iterasi-1 diperoleh.

$$
P_{1}=\sum_{i=1}^{44} \sum_{k=1}^{3}\left(\left[\sum_{j=1}^{2}\left(X_{i j}-V_{k j}\right)^{2}\right]\left(\mu_{i k}\right)^{2}\right)=12074.965
$$

Langkah selanjutnya mengecek kondisi berhenti. Dimana diperoleh nilai $\mathrm{P}_{1}-\mathrm{P}_{0}=$ 12074.965. Karena nilai $\mathrm{P}>\xi\left(10^{-5}\right)$, maka lanjut ke iterasi-2. Demikian seterusnya hingga nilai $\mathrm{P}<\xi\left(10^{-5}\right)$, dan pada kasus ini proses iterasi akan berhenti setelah iterasi ke-18. Sedangkan hasil rekapitulasi nilai fungsi obyektif (P) disajikan pada Tabel 2.

Tabel 2. Rekapitulasi nilai fungsi obyektif

\begin{tabular}{cccc}
\hline Iterasi & Nilai & Iterasi & Nilai \\
\hline 1 & 12074,97 & 10 & 2692,419 \\
2 & 9405,146 & 11 & 2691,990 \\
3 & 8711,984 & 12 & 2691,921 \\
4 & 7426,375 & 13 & 2691,909 \\
5 & 5874,307 & 14 & 2691,906 \\
6 & 3893,597 & 15 & 2691,906 \\
7 & 2882,579 & 16 & 2691,906 \\
8 & 2717,416 & 17 & 2691,906 \\
9 & 2695,404 & 18 & 2691,906 \\
\hline
\end{tabular}

Dengan nilai pusat cluster yang terbentuk pada iterasi ke-18 adalah

$$
V=\left(\begin{array}{ll}
88.55 & 93.05 \\
65.01 & 72.01 \\
34.54 & 41.54
\end{array}\right)
$$

Dari hasil clustering dapat dilihat kecenderungan suatu data untuk masuk pada cluster, yaitu:

a. C1 sebanyak 11 orang dapat diartikan kelompok yang memiliki kemampuan penalaran matematis yang baik dengan rata-rata nilai aritmatika 88.55 dan nilai statistika 93.05.

b. C2 sebanyak 25 orang dapat diartikan kelompok yang memiliki kemampuan penalaran matematis yang cukup dengan rata-rata nilai aritmatika 65.01 dan nilai statistika 72.01 .

c. C3 sebanyak 8 orang dapat diartikan kelompok yang memiliki kemampuan penalaran matematis yang kurang dengan rata-rata nilai aritmatika 34.54 dan nilai statistika 41.54 . 
Untuk lebih jelas hasil clustering kemampuan penalaran matematis dapat dilihat pada Gambar 2.

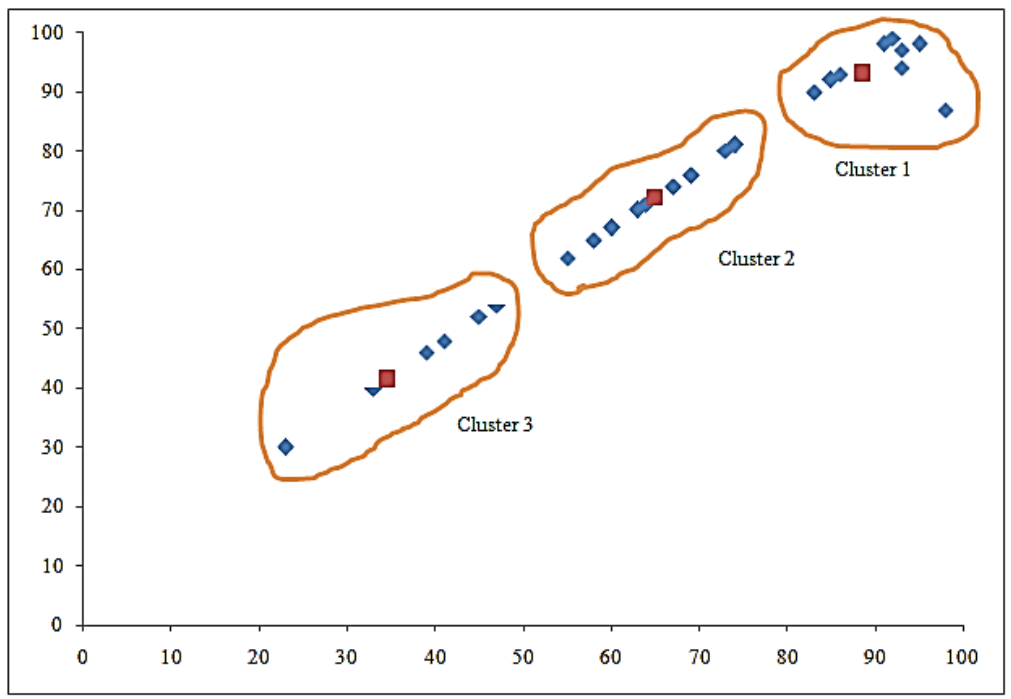

Gambar 2. Hasil clustering

Untuk menguji validitas hasil clustering sebagai evaluasi data pada setiap cluster dengan menggunakan perhitungan koefesien partisi atau Partition Coeffecient (PC) diperoleh 0,840. Dari hasil perolehan nilai validitas (PC), ini berarti dapat dikatakan bahwa hasil clustering tergolong dalam kategori baik karena nilai uji validitas mendekati angka 1 . Hasil lengkap uji validitas tiap iterasi clustering ditunjukkan pada Gambar 3.

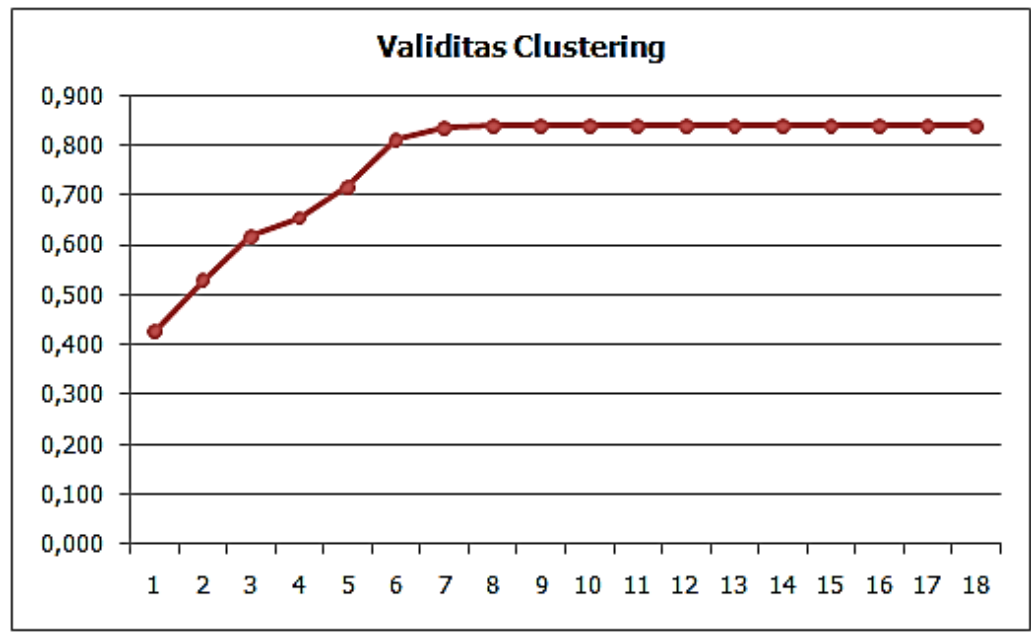

Gambar 3. Uji validitas clustering 


\section{SIMPULAN}

Berdasarkan hasil perhitungan dapat disimpulkan bahwa sebanyak 11 orang (25\%) dapat diartikan kelompok siswa yang memiliki kemampuan penalaran matematis yang baik, sebanyak 25 orang (57\%) dapat diartikan kelompok siswa yang memiliki kemampuan penalaran matematis yang cukup, dan sebanyak $8(18 \%)$ orang dapat diartikan kelompok siswa yang memiliki kemampuan penalaran matematis yang kurang. Uji validitas hasil clustering sebagai evaluasi data pada setiap cluster dengan menggunakan perhitungan koefesien partisi atau Partition Coeffecient (PC) diperoleh 0.840 , ini berarti dapat dikatakan bahwa hasil clustering tergolong dalam kategori baik.

\section{REFERENSI}

[1] Undang-undang Republik Indonesia Nomor 12 Tahun 2012 tentang Pendidikan Tinggi, ayat (b).

[2] http://sulistyomb.staff.ipb.ac.id/2011/12/23/apa-itu-ilmu-komputer, diakses 29 Agustus 2015.

[3] Universitas Pendidikan Indonesia. 2008. Rujukan Filsafat Teori dan Praksis Ilmu Pendidikan. Bandung, UPI Press.

[4] Anisah., Zulkardi., dan Darmawijoyo. 2015. Pengembangan Soal Matematika Untuk Mengukur Kemampuan Penalaran Matematis Siswa (http://download. portalgaruda.org, diakses tanggal 29 Agustus 2015).

[5] Jain, A. K., Murthy, M. N. \& Flynn, P. J. 1999. Data Clustering: A Review. ACM Computing Surveys, Vol. 31, No. 3.

[6] Hammouda, K., Karaay, F. 2000. A Comparative Study of Data Clustering Techniques. University of Waterloo, Ontario, Canada.

[7] Kusumadewi, S., Hartati, S., Harjoko, A., Wardoyo, R. 2006. Fuzzy MultiAttribute Decision Making (Fuzzy MADM). Graha Ilmu, Yogyakarta.

[8] Zimmermann. 2001. Fuzzy Set Theory and Its Applications, Fourth Edition. Kluwer Academic Publishers.

[9] Bezdek, James. 1981. Pattern Recognition With Fuzzy Objective Function Algorithms. Plenum Press, New York. 
